Relations industrielles

Industrial Relations

\title{
Workers' Compensation: Foundations for Reform edited by Morley GUNDERSON and Douglas HYATT, Toronto: University of Toronto Press, 2000, 360 pp., ISBN 0-8020-4453-0.
}

\section{Mark Thompson}

Volume 57, numéro 3, été 2002

URI : https://id.erudit.org/iderudit/006890ar

DOI : https://doi.org/10.7202/006890ar

Aller au sommaire du numéro

Éditeur(s)

Département des relations industrielles de l’Université Laval

ISSN

0034-379X (imprimé)

1703-8138 (numérique)

Découvrir la revue

Citer ce compte rendu

Thompson, M. (2002). Compte rendu de [Workers' Compensation:

Foundations for Reform edited by Morley GUNDERSON and Douglas HYATT,

Toronto: University of Toronto Press, 2000, 360 pp., ISBN 0-8020-4453-0.]

Relations industrielles / Industrial Relations, 57(3), 572-574.

https://doi.org/10.7202/006890ar

Tous droits réservés @ C Département des relations industrielles de l’Université Laval, 2002
Ce document est protégé par la loi sur le droit d'auteur. L'utilisation des services d'Érudit (y compris la reproduction) est assujettie à sa politique d'utilisation que vous pouvez consulter en ligne.

https://apropos.erudit.org/fr/usagers/politique-dutilisation/ 


\title{
Recensions
}

\section{Book Reviews}

\author{
Workers' Compensation: Foundations for Reform \\ edited by Morley GUNDERSON and Douglas HyATT, Toronto: University of \\ Toronto Press, 2000, 360 pp., ISBN 0-8020-4453-0.
}

British Columbia enacted the first workers' compensation law in Canada in 1902. Other provinces passed similar legislation in the following 20 years. All were based on the "historic compromise," whereby workers injured on the job gave up the right to sue their employers and received in return a "no fault" insurance plan funded by employers. These simple concepts have evolved into a major social institution, combining elements of regulation (occupational health and safety), insurance (wage payments for time lost due to accident or disease) and health care (medical and rehabilitation services for insured workers). The system costs billions of dollars and is exceptionally complex. Poorly understood by the parties, the public and politicians, workers' compensation generates surprising emotion and controversy. This book contains eleven academic studies of specific issues in Canadian workers' compensation. It adds considerably to the growing Canadian academic literature on workers' compensation systems.

The editors' premise for the book, stated in the introduction, is that workers' compensation systems are in need of "drastic reform." Pressures for reform include changes in work environments and labour markets, cost pressures and unfunded liabilities. Apart from environmental forces, the editors note that virtually every province and territory in the country had examined its workers' compensation system in the 1990s.
A careful reading of the volume yields many valuable insights, but the case for drastic reform simply is not made. Viewed historically, the frequent examinations of workers' compensation systems are not rare. Through 1999, British Columbia had four royal commissions and three other government reviews of workers' compensation, more than any other public institution. When the chapters in this book were written in the mid-1990s, many provincial boards, especially Ontario, had substantial unfunded liabilities. The 2000 annual report of the Ontario Workplace Safety and Insurance Board (WSIB) (the latest available to the public) reported a surplus of revenues over costs for six consecutive years, driven by reduced benefits, administrative reforms and robust returns on its investment portfolio. The unfunded liability, still substantial, has to be seen in light of fluctuations in financial markets, as well as compensation costs.

After an introduction on labour market changes written by the editors, other chapters fall into three categories: economic issues, accidents or their prevention and administration.

Looking at the most fundamental economic question, Peter Dungan examined the effects of workers' compensation and other taxes on the economies of Canada and Ontario. His sophisticated econometric techniques found that higher workers' compensation premiums 
were borne in the short run by the employer, but over the longer term these costs are transferred to workers through lower wages. To maximize efficiency, the author suggests that taxes be linked to industry and firm accident costs. In fact, Canadian jurisdictions do use "experience rating," i.e., the application of normal insurance principles of relating cost to risk, in setting premiums. Morley Gunderson and Douglas Hyatt examine the massive unfunded liability of the Ontario system in 1996. Contrary to the conventional political wisdom of the time, the unfunded liability was not a product of the New Democratic Party regime or even the Liberals who preceded them. It had been rising for fifteen years at that time. The authors relate the problem of shifting unfunded liabilities to globalization and intergenerational transfers. They also suggest that one solution might be to expand coverage of the workers' compensation system to cover workers who are less accident prone, thereby transferring resources to the existing claimants. As workers' compensation systems are administered in this country, this proposal is essentially impossible. The principle of experience rating means that industry groups and employers bear the costs of their accidents. In the case of Ontario, the largest unfunded liability was in the construction industry, a sector remotely linked to globalization. Overt crossindustry subsidies would arouse strong political opposition within the employer community. With the passage of time, the unfunded liability in Ontario looks more manageable, yet one is left wondering how responsible officials permitted it to accumulate to approximately 300 per cent of the WSIB's annual revenues.

The costs of workers' compensation are examined further by two American authors, Terry Thomason and John Burton. They compare workers' compensation costs of British Columbia, Ontario and the U.S. Of the three jurisdictions,
British Columbia is the least expensive. Despite thorough knowledge of the Canadian and American systems, they do not consider benefit levels. By and large, Canadian benefits are superior to those in the U.S. After examining overall costs, the authors grudgingly admit that the public monopolies in Canadian jurisdictions are less costly than the mixed public-private systems used in most U.S. states.

In their treatment of occupational injuries, Esther Shainblum, Terrence Sullivan and John Frank go beyond traditional analyses of causality, which arose out of heavy industry - a worker falls or is struck by an object, for example. The authors point out that social class and health are positively correlated. The implication is that the unstable low paying jobs that have become more common in the Canadian economy may be linked to industrial injuries. Speculating that heart disease may be linked to work-related factors, they point to the strains this conclusion would place on the workers' compensation system. The treatment of causality will arouse the fears of employers, but is likely to be a reference point for future discussion of the subject.

In another chapter likely to provoke debate, John Frank examines the most common source of workplace injury, lower back pain, which the current workers' compensation does not handle well. The author points to the lack of modified work programs to re-integrate injured workers into the labour force. Such a program would require injured workers to be accommodated in their workplaces, a right not found in workers' compensation legislation, as well as improved rehabilitation programs.

Workers' compensation systems are difficult to govern. Each injury causes several administrative decisions, all of which are subject to some level of appeal, a degree of transparency unknown in the private sector. In keeping with the 
"crisis" theme of the book, Donald Dewees examines the possible role for the private sector in workers' compensation systems. This chapter is a lengthy review of the theory and practice of privatization of public functions. The author concludes that some privatization must be desirable, but acknowledges that turning the entire system over to the private sector would be problematic. Again, he misunderstands the insurance principles of the system by suggesting a surtax on all employers to recover an unfunded liability.

The debate over the most effective policies to prevent accidents is ongoing. Experience rating provides economic incentives to employers. Ample evidence demonstrates that financial penalties must be supplemented by regulation. Boris Kralj examines both Canadian and American studies and concludes that regulations are more effective in reducing specific types of injury than the global accident rate. $\mathrm{He}$ also found that joint health and safety committees, required in most Canadian workplaces, reduce injuries. Overall the Canadian internal responsibility system is more effective than the U.S. regulation-based mechanism for reducing accidents. On balance, Kralj favours economic incentives, although he does not even address the moral hazard of employers who are discouraged from reporting accidents when economic penalties are high.

Workers' compensation systems were designed to reduce or eliminate litigation for industrial accidents. In a litigious society, elimination of torts claims is virtually impossible. David Law reviews the underlying causes of litigation in Ontario. His analysis is thoughtful and thorough. He points out that efforts to reduce claims costs undertaken in Ontario have the perverse effect of increasing administrative costs while cutting the benefits to injured workers.

The chapter by Hyatt and Law ends the book by going back to the roots of the historic compromise, comparing torts and workers' compensation as techniques for resolving disputes over injuries. Although workers pay up to 85 per cent of the costs of the system (through lower wages), they receive awards that seem modest when compared to injuries sustained outside of the workplace. To test this proposition, the authors compare the results of injuries in the British Columbia workers' compensation system and a tort regime and found that the former provided greater benefits for workers. They note in passing that about half of all costs of a tort system are consumed by administration, thereby hinting at the paradox of U.S.Canadian cost comparisons. The American system has more litigation, lower benefits and higher costs. Presumably the American system is more generous to trial lawyers than public monopolies in Canada. However, the authors suggest that workers would benefit from an expansion of the right to sue for industrial accidents.

For persons interested in workers' compensation, this book is invaluable. The review articles summarize a large body of research, and the empirical chapters shed new light on the system, which needs adjustment, but not wholesale change. Recent events in British Columbia illustrate this point. A rightwing government was elected after promising to "reform" the workers' compensation system. A managementside lawyer advised the new government against fundamental change, so it fulfilled its promise by cutting benefits to injured workers and streamlining appeal procedures. Reduction of the "regulatory burden" of health and safety regulations is scheduled. Doubtless another legislative inquiry/royal commission will be necessary to assess the effects of these changes in the future.

MARK ThOMPSON

University of British Columbia 